Annals of Warsaw University of Life Sciences - SGGW

Land Reclamation No 38, 2007: 33-40

(Ann. Warsaw Univ. of Life Sci. - SGGW, Land Reclam. 38, 2007)

\title{
Changes in the reserves of soil retention of arable lands in Central Sudety
}

\author{
GRZEGORZ PĘCZKOWSKI, STANISŁAW KOSTRZEWA, \\ WOJCIECH ORZEPOWSKI \\ Institute of Environmental Development and Protection \\ Wroclaw Uniwersity of Environmental and Life Sciences
}

\begin{abstract}
Changes in the reserves of soil retention of arable lands in Central Sudety. The project presents research involving an analysis and evaluation of water supply of poorly permeable soils in drained arable lands. The analysis dealt with research conducted in 2003-2005 at similar meteorological conditions in an agricultural submountain catchment area situated in Central Sudety. In particular, the analysis concerned water and air properties of examined deposits with regard to their water-retention. The measurements of moisture density of soil profiles and calculated water supplies in layers $1-100 \mathrm{~cm}$ showed a crosssection of reserves of soil retention. This depended on the depth and lay of the land as well as drainage conditions. In the lower drainage area at the foot of the slope there was a notably higher level of groundwater than in other places on the slope. In areas where rainfall was the exclusive source of groundwater the measured water-supplies were lower than in multi-sourced drainage areas. The amount of measured supplies for the vegetation period spanning the whole research time was not lower than $70 \%$ of the field-water capacity.
\end{abstract}

Key words: sub-mountain catchment area, soilretention, drainage.

\section{INTRODUCTION}

Adverse changes in the environment caused by human economic activity frequently give rise to a reduction of natural retention-ability of the catchment area, speeding up the water circulation in the environment (Dynowska, 1993; Mioduszewski, 1997).

An important directive is the complex handling of issues connected with developing, protecting and utilizing water supplies in agricultural catchment areas. In particular, this concerns the deterioration of the stuctural balance of water. Attention must be placed on the fact that considerable changes are taking place in the field of hill-farming techniques which has had a marked affect on balance. The main aim that we can set for research projects dealing with soil-subsystems is to estimate water supplies and to examine the influence of antropo-pressure on changes of elements in water-circulation in the catchment area in terms of quality and quantity (Radczuk, 2000; Mioduszewski, 2002).

The goal of this work is to judge the water supplies of soils in sub-mountainous lands focusing on a systematically dehydrated drainage area. This will be carried out in standard gauge sections in varied drainage conditions (multisourced and rainfall drainage) between the years 2003-2005. 


\section{MATERIALS AND METHODS}

The research subject Bogaczowice $\left(16^{\circ} 11^{\prime} \mathrm{E} ; 50^{\circ} 52^{\prime} \mathrm{N}\right)$ is situated on the borderland area of Pogórze Bolkowsko-Wałbrzyskie and Góry Wałbrzyskie in Central Sudety. The catchment area of the subject is located at the northern and north-eastern slopes 400-500 metres above sea-level. The gradients are steep and range from $52-84 \%$. The shape of the land is the result of the morphology of the Sudety, Góry Wałbrzyskie and Pogórze formed in the tertiary period (Czamara, 2001).

This catchment area is occupied mainly by arable lands partly dehydrated by systematic drainage. This work analizes in detail standard gauge sections located in the upper part (Section 11 and 12), lower part (Section 8 and 2) as well as at the foot of the slope (Section 1, Fig. 1). The subject is located in the pluvial-thermal foreland region on the border of the Wałbrzyski region (Kostrzewa, 2004). The annual rainfall for many years at the IMGW station in Szczawno Zdrój located near the subject was $655 \mathrm{~mm}$, vegetation period (April - September) $430 \mathrm{~mm}$.The average yearly temperature for many years was $7.3^{\circ} \mathrm{C}$. The highest mean monthly air temperatures differing considerably from the monthly average temperatures

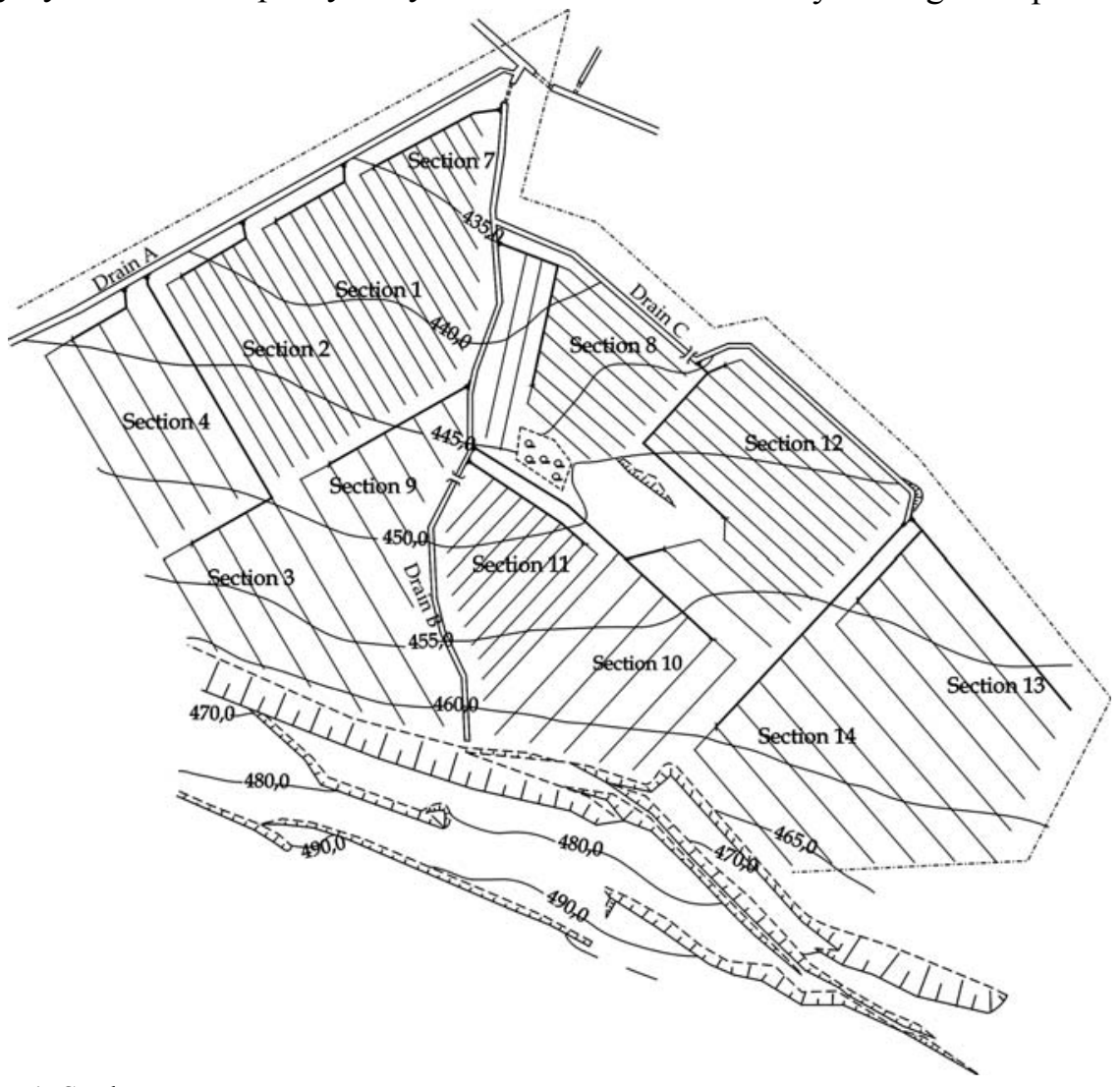

FIGURE 1. Study area 
over many years from April-September were noted from May-August 2003 and from May-July 2005. The rainfall of the vegetation period (April-September) 2003-2004 was roughly $100 \mathrm{~mm}$ lower than the rainfall over many years with the exception of May 2003 (35 mm higher than the average over many years). In May, July and August 2005, there was notably higher rainfall than the average from over many years (respectively by 17,73 and $9 \%$. The vegetation periods (April-September) for the years 2003-2004 were classified as dry with rainfall amounting to 325 and $328 \mathrm{~mm}$ and the same period for 2005 as medium wet with rainfall amounting to $448 \mathrm{~mm}$ (Tab. $1)$. On the subject there are pseudo-white soils in general having a heavy clay composition, sometimes medium clay composition with a large content of structural soil (from 15-35\%). The profiles are shallow and occur on the gravel fractions of the rocks. In the matrix in sections 1 and 2 at a depth of more than $45 \mathrm{~cm}(70 \mathrm{~cm})$ light clay and light, dusty clay were found (sand content from 34 $-46 \%$ ), whereas in section 12 medium dusty clay (up to $27 \%$ of sand), in sections 8 and 11 in sub-arable layer, exclusively heavy clay (24-34\% of sand). In the top layers the examined deposits contain from $44-57 \%$ of drift parts $13-27 \%$ of dusty fraction and $26-34 \%$ of sand fraction. The amount of water occuring in different layers was established by means of a Eijelkamp block. In particular, the amount of available water filling the mezopores $(8.5-0.2 \mathrm{~m})$ and macropores (30-8.5 m) divided into difficult (pF 2.9 -4.2 ) and easy ( $\mathrm{pF}$ 2.0-2.9) availability also gravitational water at $\mathrm{pF}$ less than 2 occupying the volume of macropores

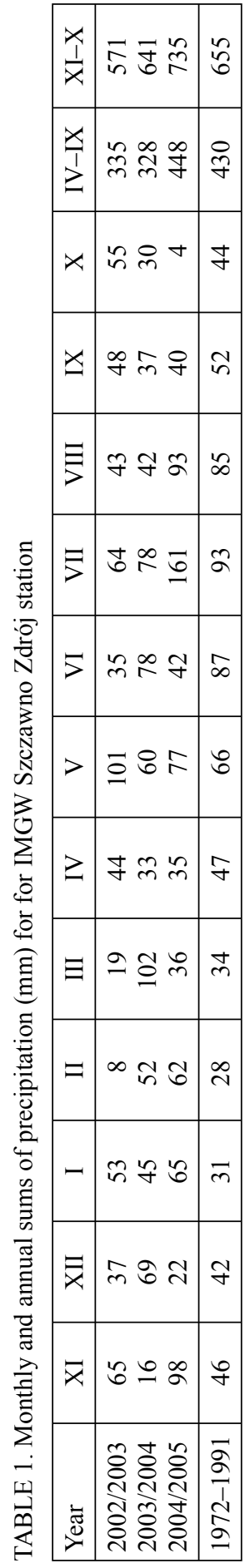


greater than $30 \mathrm{~m}$. The soils of the analyzed sections have similar water properties.

The characteristics of moisture-density and suction pressure have shown that the amount of easily available water filling mezapores and macropores with a diameter 4-30 m amounts to at most $6.8 \%$ of the volume in the arable layer (Section 2) whereas in deeper layers up to $4.7 \%$ of volume. However, the amount of water with limited availability filling mezapores $0.2-4 \mathrm{~m}$ amounts up to $19.7 \%$ of volume (Section 12). Analogously, in deeper layers these figures range to $16.9 \%$ of volume. In section 8 at a depth greater than $50 \mathrm{~cm}$ the amount of water easily available for plants is very small (to $2.6 \%$ of volume) contrariwise the amount of water with limited availability was to $14.6 \%$. In the analized profiles, the amount of water unavailable for plants (thus water in micropores with a diameter less than $0.2 \mathrm{~m}$ ) is considerable and ranges from $12.6-23.3 \%$ of volume.

\section{RESULTS AND DISCUSSION}

In order to determine the changes in soil retention reserves in the analized sections, the moisture density of soil profile in the top layer $(0-100 \mathrm{~cm})$ was measured. The moisture level was marked throughout the vegetation season by means of two methods: dry weighing and Time-Domain Reflectometry (TDR). On the basis of measured moisture density, water supplies were calculated in a 1-metre soil profile (Fig. 2). the water supplies were presented to a background of characteristic retention states, such as: $\mathrm{Z}_{1}$ - maximum acceptable water supply defined as supply by $15 \%$ air content in soil, $Z_{2}$ supply by field water capacity $(\mathrm{pF}=2.0), \mathrm{Z}_{3}$ - suppy by the absolutley smallest water capacity $(\mathrm{pF}=4.2)$.

In the dry vegetation periods in the years 2003 and 2004 and in the medium wet period (April-September) of the year 2005 , the measured water supplies in a 1-metre soil profile in the sections with multi-sourced drainage (Section 1, and 11) were usually higher (by about 5-10\%) than supplies in the sections classified as exclusively rainfall drainage. In the sections of exclusive rainfall drainage (sections 2, 8 and 12) the retention supply in a one-metre profile was not notably varied; throughout the vegetation period the differences amounted to $20-30 \mathrm{~mm}$.

The maximum supplies in soils of all sections were noted in the discussed years in the preliminary phase of vegetation period in April. These supplies mainly originated from post-winter retention supplies after the thaw in early Spring but only to a lesser degree from rainfall. It was claimed that this supply did not exceed the supply corresponding to field water capacity and it amounted to 376 $\mathrm{mm}$ (Section 1).

In the years 2003-2004 between the months of May and September the supplies of soil retention were gradually exhausted as a result of large-scale evapotranspiration as well as from modest rainfall. In the layer from 0-100 $\mathrm{cm}$, the quantity of supplies decreased to about $260 \mathrm{~mm}$ which in general constituted more than $70 \%$ of field water capacity.

The rainfall in July 2005 which was higher by $79 \%$ compared to that of many previous years did not manage to increase the retention supplies considerably in 

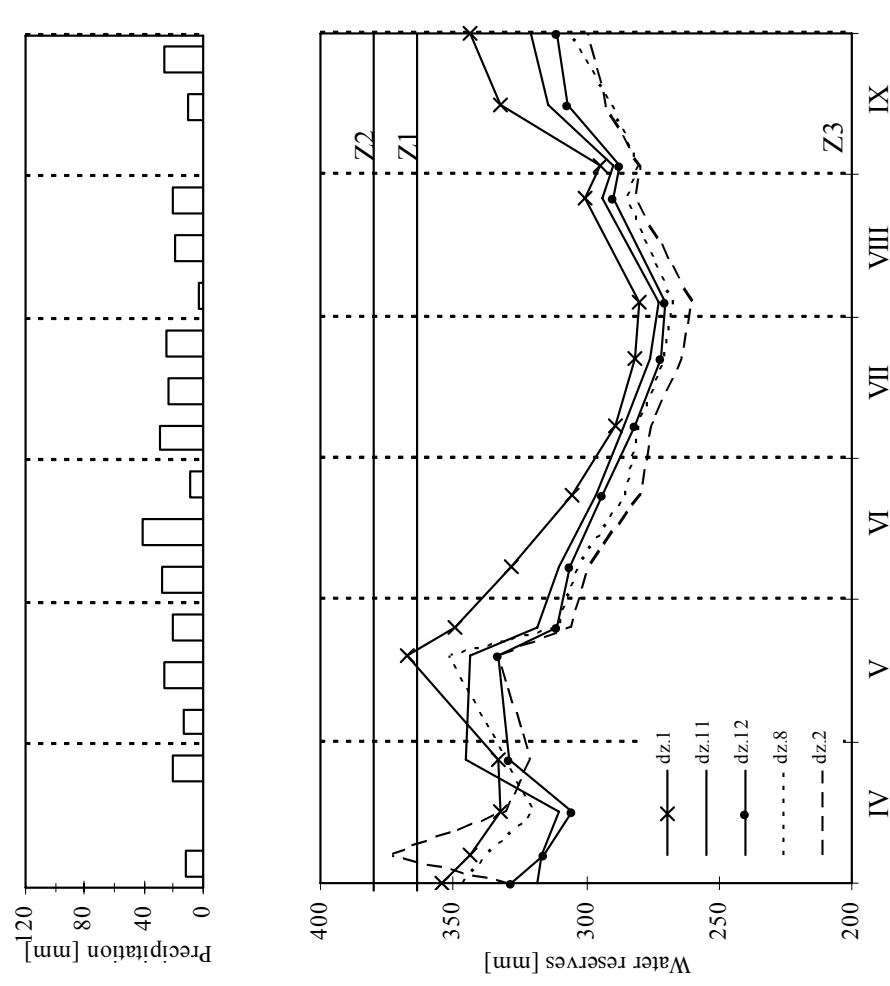

\&. $0= \pm N$ 曲 $\infty$ 䲶 $=70$ 号 क

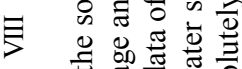
Ð .

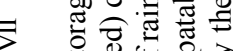
फ

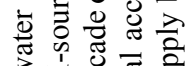

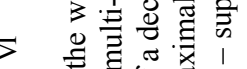

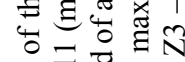
그요

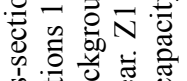
过 ல

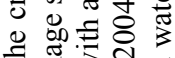

ข ปั่

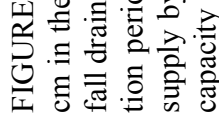
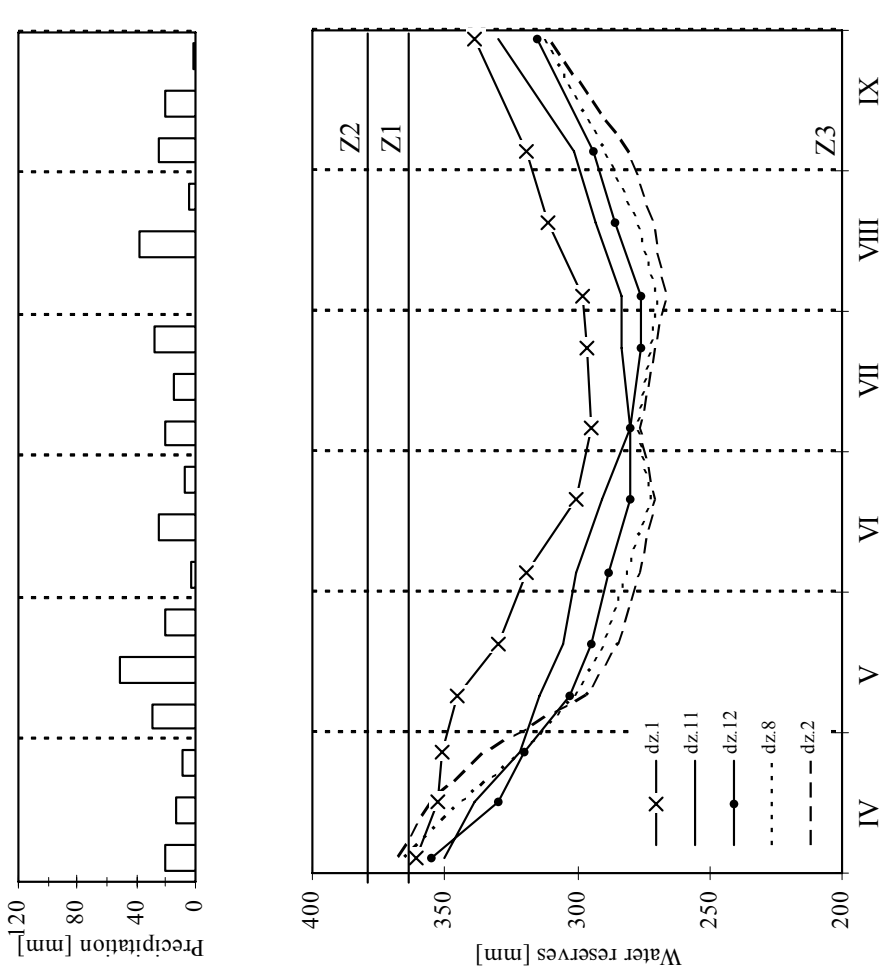

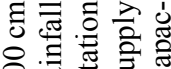
으류

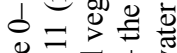
舟西 1

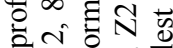

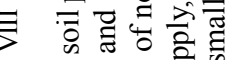

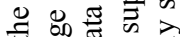
. 흉 矛 응 क 仓 प 䒕

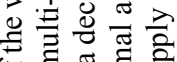
फ凷顿 .큼ํㅀ 导苛 N

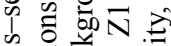
总芯

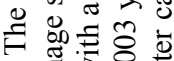
ㄱ.

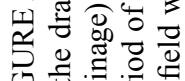

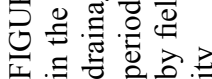



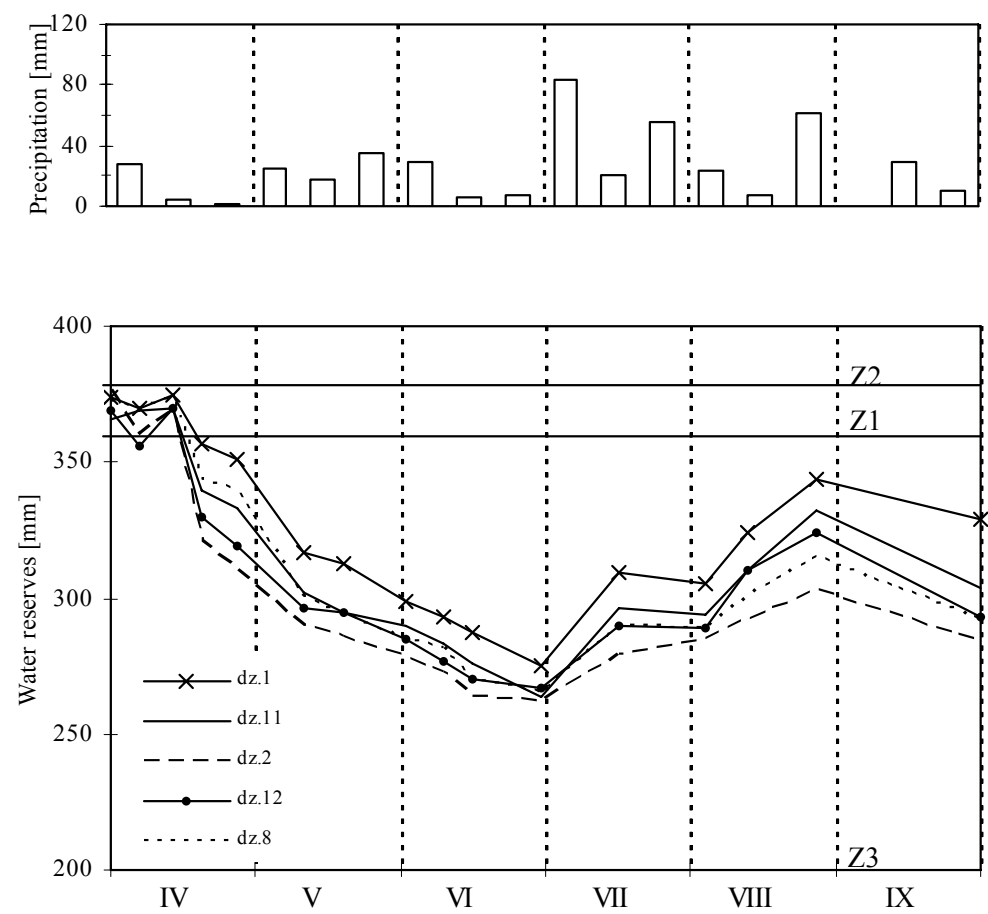

FIGURE $2 \mathrm{~b}$. The cross-section of the water storage in the soil profile $0-100 \mathrm{~cm}$ in the drainage sections 1, 11 (multi-sourced) drainage and 2,8,11 (rainfall drainage) with a background of a decade of rainfall data of normal vegetation period of 2005 year. Z1 - maximal acceptable water supply, Z2 - the supply by field water capacity, Z3 - supply by the absolutely smallest water capacity

soil profiles and especially in the layers at greater depths.

In the dry vegetation periods in 2003-2004, the lowest water supplies in soil profiles were noted between June and August. That period was characterized by higher mean monthly air temperatures compared to the that of many previous years and relatively small rainfall. In the medium wet vegetation period (April-September) of 2005 the amount of retention reserves in soil profile decreased to $69 \%$ of the field water capacity at the end of June for a short stint. However, in July and August after abundant rainfall which constituted $73 \%$ and $9 \%$ of that from many previous years the water supplies increased by about $100 \mathrm{~mm}$.

Szafrański (1993) has shown in his research that the greatest water supplies in the lake area (Pojezierze Gnieźnieńskie) occurred in soil profiles deposited in lower parts of the slope in places on the concave slope. Apart from the significant influence of the contours of the land the dynamics of changes in the water supplies depended on meteorological conditions over time in particular the rainfall. The water supplies in the soil profile, measured in the periods of modest rainfall, indicated that it was necessary to implement an operation designed to increase the retention capacity. Solarski (1996) on the basis of research on 
uneven ground in a part of the lake area Pojezierze Mazurskie claimed there was a significant influence of intensive contour change on the land on variability of water conditions and in particular soil moisture-density which is largely modified by the gradient of the land. The valleys and the base of the slopes usually showed an excess of soil moisture as a result of additional drainage from runoff at higher altitudes.

\section{CONCLUSIONS}

1. The characteristic structure of the soil profile occurring on the gravel fraction of the rock, composed mainly of heavy clays, was a contributing factor, to the fact that in the dry vegetation season in the years 2003 -2004 soil retention reserves collected in the winter period were rapidly exhausted down to the value of $70 \%$ of the field water capacity, whereas in the medium wet vegetation period of the year 2005, they were higher by 50-100 $\mathrm{mm}$.

2. The supplies maximum values were noted in the analized periods in the preliminary phase of the vegetation period in April. These supplies originated mainly from the post winter retention reserves after the early Spring thaw but only to a lesser degree did they originate from rainfall.

3. In the base section of the slope (Section 1) the water supplies in a 1 metre soil profile were in general higher by about $20 \mathrm{~mm}$ than in slope sections (Section 2, 8, 11 and 12).
4. The values of the measured water supplies in a one metre soil profile in the sections with multi-sourced drainage were higherby up to $40 \mathrm{~mm}$ than in the rainfall drainage sections.

Study conducted within the realization scope of project KBN No 2PO 6S 063 26.

\section{REFERENCES}

CZAMARA A. 2001: Charakterystyka warunków fizjograficznych zlewni górnej Strzegomki. Zesz. nauk. AR Wroc. ser. Inż. Srod. XII, 413, p. 245-255.

DYNOWSKA I. (red.) 1993: Przemiany stosunków wodnych w Polsce w wyniku procesów naturalnych i antropogenicznych - UJ, Kraków, p. 380.

KOSTRZEWA S., PECZKOWSKI G., STRZELCZYK M. 2004: Sprawność drenowania gleb ornych w Sudetach Środkowych. Acta Scient. Pol. Kształt. Środ. 3 (1) p. 73-79.

MIODUSZEWSKI W. 1997: Mała retencja i polityka melioracyjna. Zesz. Nauk. Komitetu „Człowiek i Środowisko”, 17, p. 49-62.

MIODUSZEWSKI W. 2002: Kształtowanie zasobów wodnych w obszarach rolniczych. Wiad. Melior. i Łąk, 1.

RADCZUK L. 2000: Rola zlewni eksperymentalnych w badaniach interdyscyplinarnych. Zesz. Nauk. AR we Wroc. Inż. Środ. 11 nr 385, p. 309-314.

SOLARSKI H., RUDZKI R., FIEDORUK P. 1986: Problemy drenowania gruntów na Pojezierzu Mazurskim. Wiad. Melior. i Łąk, 2.

SZAFRAŃSKI C. 1993: Gospodarka wodna gleb terenów bogato rzeźbionych i potrzeby ich melioracji. Rocz. AR w Poznaniu, Z. 244. 
Streszczenie: Zmiany zasobów retencji glebowej zdrenowanych gruntów ornych w Sudetach Srodkowych. Badania przedstawione w pracy obejmujace analize i ocene gospodarki wodnej gleb słabo przepuszczalnych zdrenowanych gruntów ornych. Analiza objęła badania przeprowadzone w latach 2003-2005 o zbliżonych warunkach meteorologicznych w rolniczej zlewni podgórskiej, położonej w Sudetach Środkowych. Szczegółowo analizowano właściwości powietrzno-wodne badanych utworów $\mathrm{z}$ uwagi na ich retencyjność. Przeprowadzone pomiary uwilgotnienia profilów glebowych i obliczone na tej podstawie zapasy wody w warstwie $0-100 \mathrm{~cm}$ wykazały zróżnicowanie rozkładu zasobów retencji glebowej w zależności od położenia w rzeźbie terenu, jak i warunków zasilania. W dziale drenarskim położonym w niższych partiach terenu, u podnóża zbocza notowano wyższe zapasy wody glebowej niż w miejscach położonych na stoku. W działach o zasilaniu wyłącznie opadowym pomierzone zapasy wody były niższe niż w działach o zasilaniu złożonym. Wielkość obliczonych zapasów w okresie wegetacyjnym w całym cyklu badań nie była niższa niż $70 \%$ polowej pojemności wodnej.

\section{MS. received November 2007}

\section{Authors' address:}

Grzegorz Pęczkowski, Stanisław Kostrzewa, Wojciech Orzepowski

Institute of Environmental Development and

Protection

Wrocław University of Environmental and Life

Sciences

pl. Grunwaldzki 24, 50-363 Wrocław,

Poland

e-mail:polt@ozi.ar.wroc.pl

e-mail:imel@miks.ar.wroc.pl

e-mail: orzepow@miks.ar.wroc.pl 